\section{9. 大学生の体高活较に対する堭度についての研究}

龍谷大学渡辺惫一

1.この研究は大学生における体育活動への参加の状

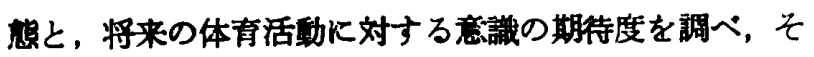
の間にどのような咸保が存在するかを明らかにするため に䘕なったものである.

2.この調查は昭和 42 年 6 月〜11月にかけて龍谷大学 と立命館大学の学生に対し筫問紙法により調査を行なっ た。

3. 大学生の日常生活における 体青活動は全体の $28 \%$ の学生が運動を行なっていない状隼にあり，その他大部 分の学生はなんらかの形で体育活動を行なっていること がかかった．さらに体育活動に対する爫生の意識はその $7.6 \%$ ののが現在の体青活動に対し「不旮分である」 と答えており，「充分である」と答えたものは12.9\%に すぎなかつた。

将来の体育活動に対する学生の意識をみると積函的態 度を示するのが $41.4 \%$ 占め $12.4 \%$ ののが消極的態度 を占めているが，将来の体育活動に対する意識と現在の 体育活動の参加状熊を比较してみると，現在の体育活動 に対し满足しているものよりも不満足な態变を示すもの の方が将来の体育活動に対する意識に樌極さが強く表わ
れている. 又体育活動への参加の回数の多い者程将米に 対する体育活動の意議は棈厔的になり，参加の回数の少 ない者程将来に対する意識は消儌以になる㑯向を示して いることがわかつた.

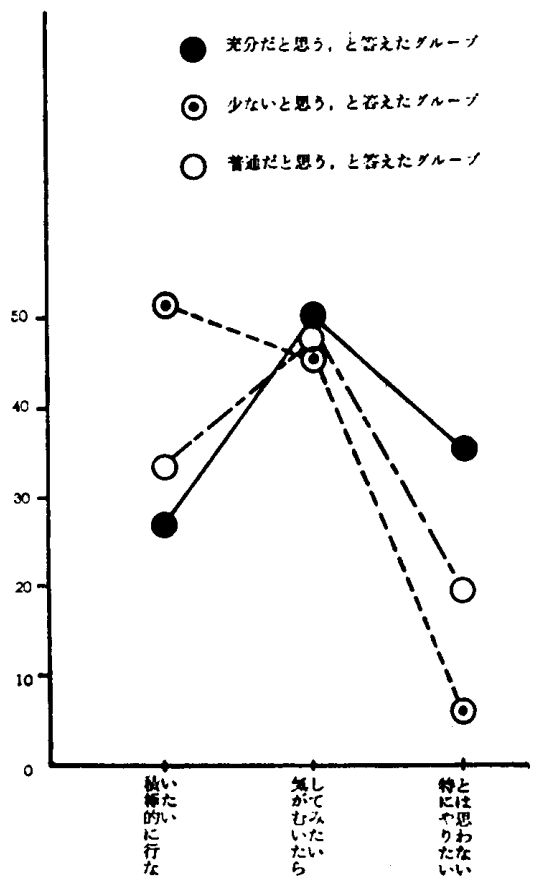

4. 学生の体 育活娌の状態 はかなり制限 された状隹て 行なわれてお り大部分の学 生が体育活就 に対し不洲足 な状隹におか れており，又 将来の体育活 動に対する意 識では積怄的 意識をるつも のと消标的意 裁をるつもの の間に意識の 差が大きな る傾向がある

\section{0. 学生生活とスポーツ活助に阙する社会学的研究}

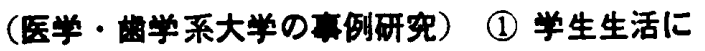
しめるスポーツ活勅の位国について

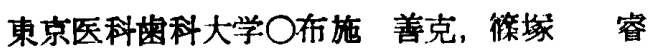

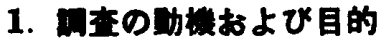

スポーツの科学的研究の第一歩は医学によってもたら された. 現在，医学を志さす学生はスポーツにどのよう な関心を，どの程度もっているのかを知りたいと思った のが,この研究の動機である.

医学・迷学系学生は教菱部 2 年，学部 4 年, つこう6 年間の学生生活を送る. 学生生活におけるスポーツ活動 の現状（教科体有を除く）を生活構造，社会的背景，意 識・熊度等と開連させながら，特に教养部と学部という 角度から明らかにしたい。

\section{2. 的查の方法・時期}

質問紙法，昭和 43 年 4 月下旬

\section{3. 対}

千菜県市川市に教無部があり，都心に学部及び付属病 院を持つ東京医科科大，日本医科大，東京科大学の 教善部 2 年男子 347 名，女子 47 名，学部 2 年男子 193 名，女子18名である。

\section{4. 周查の结果}

女子の標本が非常に少ないのでここでは男子の結果 のみを啹告する。

(1) 释渚的に恵まれた学生が多く，クラブの技術的水 潐も高くないため部所属率は高い.

(2) 休及時間等学内で行ならスポーツ活動は教美部て は活発たが，スポーツ施設のはとんどない学部では低調 である。

(3) 学部の部所属者は実習・実殹科目が大部分である ため午後 5 時まで拘束され，また大部分の運動施設が数 堆部にあるため，いきおい週末，休日練習が多くなる。

(4) 野外洎䣦，商策スポーツ施設等学外でのスポーツ 活動は教養・学部にかかわらず盛んに行なっている．学 部の学生では卒業後の生活に備えてか、ゴルフへ志向す る㑯向が強い。

(5) 教善部の生活汇ついては，比较的時間的な自由及 び施設に恵まれているためか，スボーツを十分に楽し み，かつ身伖をきたえておこうという傾向が強い。

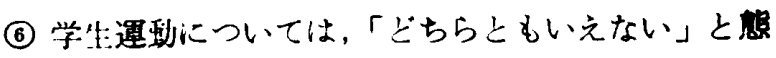
度を明確に表明しない者が大部分であるが，しいていえ

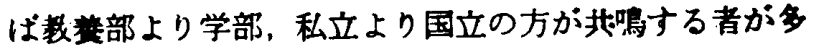
い. 